\title{
First record of the Berber ponyfish Leiognathus berbis Valenciennes, 1835 (Osteichthyes: Leiognathidae) from Syrian marine waters (Eastern Mediterranean)
}

\author{
Firas Alshawy*, Murhaf Lahlah and Chirine Hussein
}

\begin{abstract}
Background: Climatic changes and human activities have worked to pave the way for alien species to invade new areas far from their native habitat. The Mediterranean sea has received many invasive species (Eissa and Zaki, Procedia Environmental Sciences 4:251-259, 2011; Occhipinti-Ambrogi, Marine Pollution Bulletin 55(7):342-352, 2007), and some of these species had been recorded in the Syria coastal (Saad, Turkish Journal of Fisheries and Aquatic Sciences 5:99-106, 2005). Method: One specimen of the Berber ponyfish Leiognathus berbis, with a total length of $78 \mathrm{~mm}$, was caught by gillnet at a depth of 35 m, where the bottom is sandy soft, on 05 May 2016, in Syrian marine waters at Ibn Hani area (The Eastern Mediterranean Sea).

Results: This study reports that Berber ponyfish Leiognathus berbis, a member of Lessepsian species, was found in Syrian marine waters and recorded for the first time there.

Conclusion: This is the first record for Leiognathus berbis in the Syrian costal waters, and observations for the first time from the fishermen, There are several factors helped this specimen to arrive to this area of Mediterraean; one of these factors is ballast water.
\end{abstract}

Keywords: Leiognathus berbis, Lessepsian, Mediterranean, Berber ponyfish, Syrian costal

\section{Background}

Climatic changes and human activities have worked to pave the way for alien species to invade new areas far from their native habitat. The climatic changes have made the environmental conditions suitable for these species and similar to their original habitat in terms of temperature, salinity and food. While leading human activity, the opening of the Suez Canal, and the movement of ships across the world, is an important factor for making the road, which was impassable, for the fish species to move into new marine environments (Occhipinti-Ambrogi 2007, Eissa and Zaki 2011). The Mediterranean sea has received many invasive species coming from the Atlantic, Pacific and Red Sea. Many species have invaded the Mediterranean species, and settled in, because the marine

\footnotetext{
* Correspondence: falshawy@gmail.com

Department of Marine Biology, High Institute of Marine Research, Tishreen University, Lattakia, Syria
}

environment has become suitable for their growth and reproduction (Golani 1998a, Golani 1998b, Oral 2010). To this day, new marine organisms still reach the Mediterranean; of these organisms, those belonging to the family Leiognathidae: Small to medium-sized fish (rarely exceeding $16 \mathrm{~cm}$ ); body oblong or rounded, moderately to markedly compressed laterally. Eyes moderate to large. Mouth highly protractible, when extended forming a tube directed either upwards (Secutor spp.), forward (Gazza spp.), or forward or downward (Leiognathus spp.). Color :silvery, with characteristic markings on the upper half of sides which are useful for identification (Capenter and Niem 2001, Abraham et al. 2011). In reference to the ocean biogeographic information system (http://www.iobis.org/) and the encyclopedia of life (http://www.eol.org/), the family Leiognathidae exists in water's temperature range $(18.528-28.954)^{\circ} \mathrm{C}$, and salinity (32.183-35.468) PPS. 


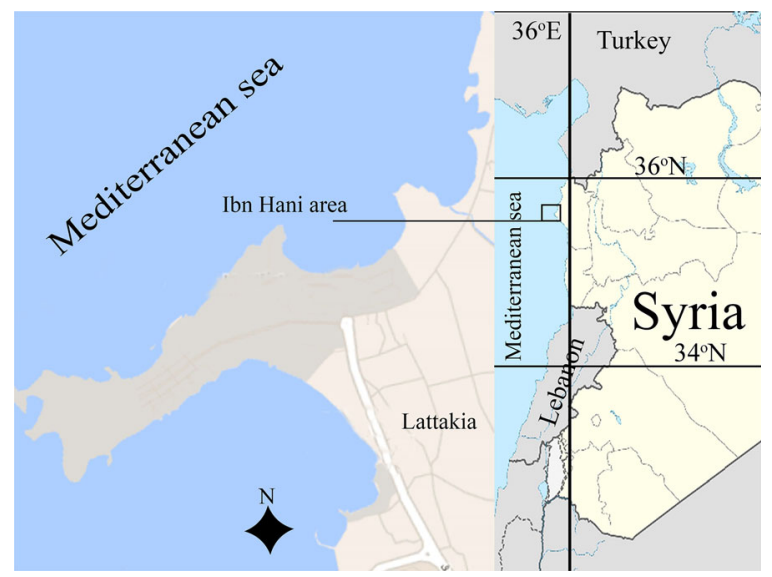

Fig. 1 A map showing the collection site of the specimen from the Syrian marine water (According Google earth)

\section{Methods}

The fish sample was collected during May 2016 from Ibn-Hani, Lattakia, Syria (Latitude:35.591632 ${ }^{\circ}$, Longitude:35.732343) (Fig. 1). On 15/05/2016, one specimen of Leiognathus berbis was carried out by using gillnet, with a mesh size is $15 \mathrm{~mm}$, at a depth of $35 \mathrm{~m}$; the bottom of the fishing zone is sandy soft mixed with some little stones; the net had been deployed in the coastal water for five hours (from 1 am to $6 \mathrm{am}$ ). The morphometric measurements and meristic details were recorded for this fish, and conserved at the fish biology lab of the Higher Institute of marine Research, Tishreen University (lenght to the nearest $\mathrm{mm}$,weight to the nearest gram). This sample was identified according to (Carpenter and Niem 2001), depending on the morphological characters. The head length, the caudal fin length and the eye diameter were measured by vernier caliper as in the Fig. 2. The specimen was preserved in $4 \%$ formaldehyde.

\section{Results}

In the current study, the specimen Leiognathus berbis (Fig. 3a) has the following properties: compressed body and elongated body more than the depth of the body, dorsal and ventral sides are convex, and mouth tapering and downward when protracted (Fig. 3b); the dorsal side is greenish with light gray and contains dark irregular vermiculations. The ventral side is coloured with belly gray; the base of anal and caudal fin are light yellowish. The morphometric measurements are shown in Table 1. The meristic data were: D VIII + 16; P,16; V, I + 5; $\mathrm{A}, \mathrm{III}+15$, the features of Leiognathus berbis are in agreement with (Chakrabarty et al. 2010). The sex of the fish is male. The bottom of fishing zone is soft sandy; it is similar to the bottom in the native region of this species (Carpenter and Niem 2001), and is convenient for feeding on benthic invertebrates. The temperature of fishing area is (27.5) ${ }^{\circ} \mathrm{C}$, and the salinity (38.2) PPS on $15 / 05 / 2016$; this parameters are close to that are found in the native habitat.

\section{Discussion}

The specimen of Leiognathus berbis lives from Madagascar to the Red Sea and the Gulf of Aden, along the Indian coasts and off Sri Lanka, eastward to Malaysia, Indonesia, and the Philippines; north to Taiwan and Fukien provinces of China; prefers coastal inshore water as a habitat; at a depth of about $40 \mathrm{~m}$ (Carpenter and Niem 2001); and has never been recorded in the Syrian coast before (Saad 2005, Ulman et al. 2015); this fish has been registered in the Suze gulf in 2005 (El-Ganainy et al. 2005). This led to arrival of

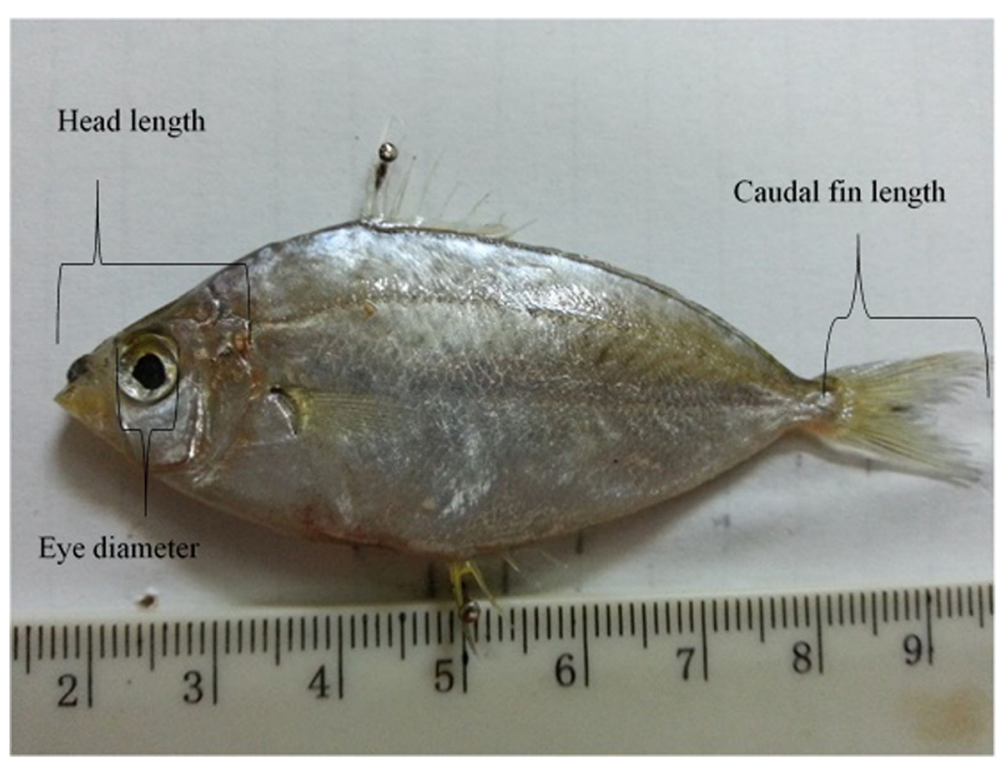

Fig. 2 The head length, the caudal fin length and the eye diameter of the fish 


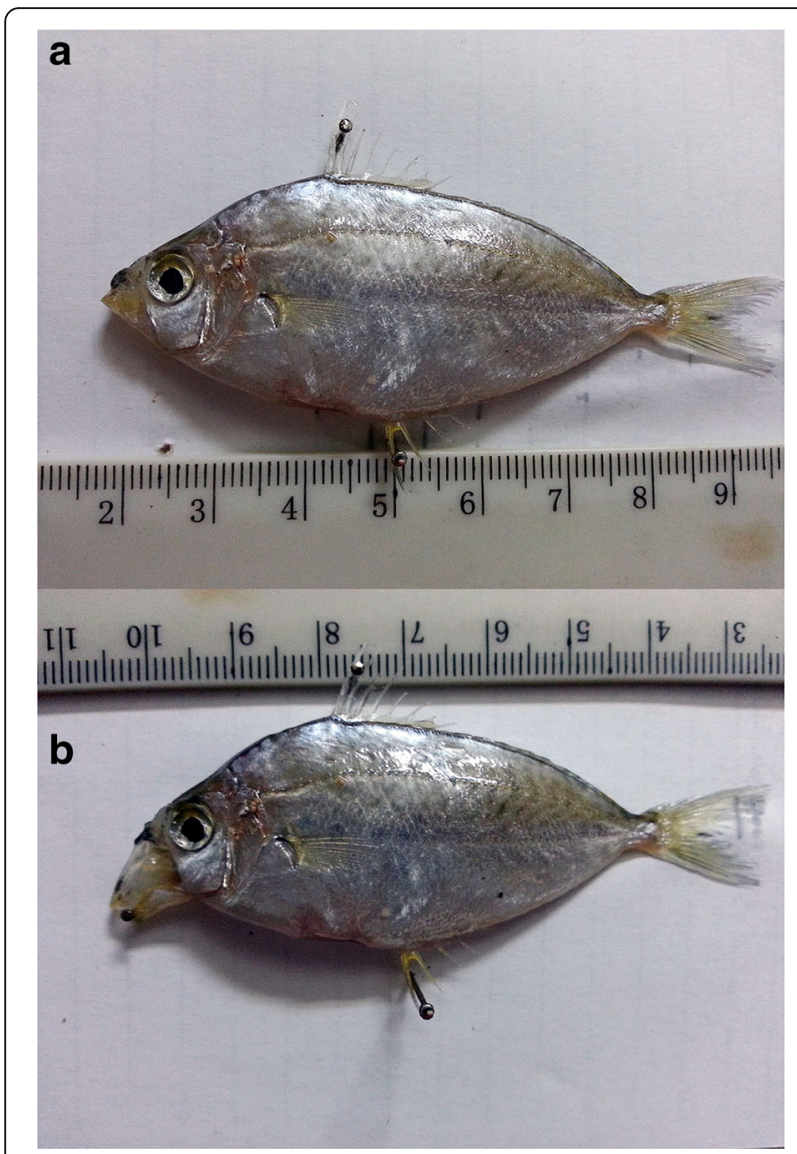

Fig. 3 Leiognathus berbis (Valenciennes, 1835) (a: general view, b: the shap of fish's mouth when feed) with78 mm total f3:2 length, was carried out during May 2016, from Ibn_Hani area (Lattakia-Syria)

the specimen of Leiognathus berbis from the Gulf of Suez, where the hydrological factors are very close to those found in the Mediterranean Sea; they moved then through the Suez Canal to reach the Syrian coastal. A new Suez Canal had been opened on 9 August 2015, which has made a big chance for fish to move into the Mediterranean sea. On other hand, the climatic changes in the world, especially in the eastern Mediterranean, are making the environment very suitable for invasive species in terms of the temperature, food, and the place for reproduction (Sorte et al. 2010). One point of view explaining the arriaval of this types of fish to

Table 1 Morphometric measurements of Leiognathus berbis was caputuer from syrian coastal water during May 2016

\begin{tabular}{ll}
\hline Morphometric Measurements & \\
\hline Total length & $78 \mathrm{~mm}$ \\
Stander length & $64 \mathrm{~mm}$ (82.05\% Total Length) \\
Head length & $16 \mathrm{~mm}$ (20.51\% Total Length) \\
Caudal fin length & $13 \mathrm{~mm}$ (16.66\% Total Length) \\
Eye diameter & $4.7 \mathrm{~mm}$ (6.02\% Total Length) \\
Total weight & $6.12 \mathrm{~g}$ \\
\hline
\end{tabular}

the Syrian coast is that the small size of Leiognathus berbis allows it to move through the ballast water. This is the first record for Leiognathus berbis which is spreading from the Indian Ocean to the Red Sea (Carpenter and Niem 2001); this result shows that the waters of the Syrian coastal water has become more convenient than before to the invasive species which they will compete with the native species; it is possible that the invasive species would become useful by entering into the food chains of other marine organisms, allowing the increase of species and diversity in the new area, particularly in the eastern basin of the Mediterranean (Dial and Roughgarden 1998).

\section{Conclusion}

This is the first record for Leiognathus berbis in the Syrian costal waters, and the first time they are observed by fishermen; this indicates that there are several factors helped this specimen to arrive to this area of Mediterraean such as ballast water.

\section{Acknowledgements}

The authors thank Tishreen University and the High Institute of Marine Research, Lattakia who provided the financial and logistic supports to this work.

\section{Funding}

The University of Tishreen, Syria.

\section{Authors' contributions}

All authors have equal participation in this work. All authors read and approved the final manuscript.

\section{Competing interests}

The authors declare that they have no competing interests.

\section{Consent for publication}

Not applicable.

\section{Ethics approval and consent to participate Not applicable.}

Received: 10 August 2016 Accepted: 10 November 2016 Published online: 17 November 2016

\section{References}

Abraham K, Joshi K, Murty VS. Taxonomy of the fishes of the family Leiognathidae (Pisces, Teleostei) from the West coast of India. Zootaxa. 2011; 2886:1-18.

Capenter K, Niem V. The living marine resources of the Western Central Pacific: vol 5 bony fishes part 3 (Menidae to Pomacentridae). Roma: Food and Agriculture Organization of the United Nations; 2001.

Carpenter $\mathrm{KE}$, Niem VH. FAO species identification guide for fishery purposes. The living marine resources of the Western Central Pacific. Volume 5. Bony fishes part 3 (Menidae to Pomacentridae). FAO Library; 2001.

Chakrabarty P, Chu J, Nahar L, Sparks JS. Geometric morphometrics uncovers a new species of ponyfish (Teleostei: Leiognathidae: Equulites), with comments on the taxonomic status of Equula berbis Valenciennes. Zootaxa. 2010; 2427(1):15-24

Dial R, Roughgarden J. Theory of marine communities: the intermediate disturbance hypothesis. Ecology. 1998;79(4):1412-24.

Eissa AE, Zaki MM. The impact of global climatic changes on the aquatic environment. Procedia Environmental Sciences. 2011;4:251-9.

El-Ganainy AA, Yassien MH, Ibrahim EA. Bottom trawl discards in the Gulf of Suez, Egypt. Egypt J Aquat Res. 2005;31:240-55.

Golani D. Distribution of Lessepsian migrant fish in the Mediterranean. Italian Journal of Zoology. 1998a;65(sup1):95-99 
Golani D. Impact of Red Sea fish migrants through the Suez Canal on the aquatic environment of the Eastern Mediterranean. Bulletin Series Yale School of Forestry and Environmental Studies. 1998b;103:375-87.

Occhipinti-Ambrogi A. Global change and marine communities: alien species and climate change. Mar Pollut Bull. 2007;55(7):342-52.

Oral M. Alien fish species in the Mediterranean-Black Sea Basin. Journal of the Black Sea/Mediterranean Environment. 2010;16(1):87-132.

Saad A. Check - list of Bony Fish Collected from the Coast of Syria. Turk J Fish Aquat Sci. 2005;5:99-106.

Sorte CJ, Williams SL, Zerebecki RA. Ocean warming increases threat of invasive species in a marine fouling community. Ecology. 2010;91(8):2198-204.

Ulman A, Saad A, Zylich K, Pauly D, Zeller D. Reconstruction of syria's fisheries C atches from 1950-2010: signs of overexploitation. Acta Ichthyol Piscat. 2015; 45:3-259.

Submit your next manuscript to BioMed Central and we will help you at every step:

- We accept pre-submission inquiries

- Our selector tool helps you to find the most relevant journal

- We provide round the clock customer support

- Convenient online submission

- Thorough peer review

- Inclusion in PubMed and all major indexing services

- Maximum visibility for your research

Submit your manuscript at www.biomedcentral.com/submit 